\title{
Potential contribution of organosilicon compounds to reduced leaching of biocides in wood protection
}

\author{
Liesbeth De VetTER $^{1 *}$, Griet DePrAetere ${ }^{2}$, Marc STEVens $^{1}$, Colin JANSSEN ${ }^{2}$, Joris VAN ACKeR ${ }^{1}$ \\ ${ }^{1}$ Ghent University, Faculty of Bioscience Engineering, Laboratory of Wood Technology Coupure Links 653, 9000 Gent, Belgium \\ ${ }^{2}$ Ghent University, Faculty of Bioscience Engineering, Laboratory of Environmental Toxicology and Aquatic Ecology, \\ Research Group Environmental Toxicology, J. Plateaustraat 22, 9000 Gent, Belgium
}

(Received 25 April 2008; revised version 24 September 2008; accepted 29 October 2008)

\author{
Keywords: \\ biocide / \\ decay resistance / \\ ecotoxicology / \\ leaching / \\ silicone / \\ wood protection
}

\begin{abstract}
- Leaching of biocide treated wood leads to reduced effectiveness and potential threat to the environment.

- Therefore the effectiveness of organosilicons as protective systems of biocides was evaluated. Scots pine sapwood specimens were impregnated with solely organosilicons and biocides as well as with combinations of both.

- The biocides 3-iodo-2-propynylbutylcarbamate, propiconazole and 3-(trimethoxysilyl)propyldimethyloctadecyl ammonium chloride confirmed their effectiveness regardless the addition of an organosilicon. Low leachate toxicities to the crustacean Daphnia magna were found for the organosilicons, whereas significant leachate toxicities were measured for the biocides. Combining both did not considerably diminish the leachate toxicities.

- It must therefore be concluded that under the circumstances as described in this article, organosilicons do not interfere with the efficacy of the biocides, but they do not contribute to a reduced leaching of the biocides either.
\end{abstract}

\begin{abstract}
Résumé - Contribution potentielle des composes à base d'organosilicone pour réduire le lessivage de biocides dans le domaine de la protection du bois.

- Le lessivage de bois traité avec des biocides conduit à une perte d'efficacité du traitement et à une menace pour l'environnement.

- Nous avons donc évalué l'efficacité des organosilicones en tant que systèmes de protection des biocides. Des échantillons d'aubier de pin sylvestre ont été imprégnés selon trois modalités (i) avec uniquement des organosilicones, (ii) avec des biocides et (iii) avec une combinaison des deux.

- Les biocides 3-iodo-2-propynylbutylcarbamate, propiconazole et 3- (trimethoxysilyl) propyldimethyloctadecyl chlorure d'ammonium ont confirmé leur efficacité quelle que soit l'organosilicone ajouté. Pour les traitements à base d'organosilicone, nous avons trouvé une faible toxicité des lixiviats (pour Daphnia magna) et une toxicité significative dans le cas des biocides seuls.

- On peut conclure que dans les conditions expérimentales présentées les organosilicones n'interfèrent pas avec l'efficacité des biocides mais ils ne contribuent pas à une réduction de la lixiviation des biocides.
\end{abstract}

\section{INTRODUCTION}

Biocides are often applied by impregnation to protect less durable wood from degrading organisms. Practice has revealed that a lot of these biocides are subjected to leaching, potentially harming other living organisms. Furthermore, once the retention of the biocides in the wood falls below a certain threshold, the retained biocides are no longer able to protect the wood adequately. It has been suggested that water repel-

*Corresponding author: liesbeth.devetter@ugent.be lents like oils, waxes and silicones, can be combined with biocides for wood in use class 3 conditions being outdoor usage out of ground contact (Donath et al., 2006a; 2006b). The primary purpose of these products is to interfere in the woodmoisture relation to protect the wood, but they are also supposed to prevent leaching of biocides during service life (Donath et al., 2006a; 2006b; Mai and Militz, 2004; Taylor and Cooper, 2003; Zahora, 2000). Their suitability, mode of action and location inside wood once applied has been investigated (De Vetter et al., 2006; De Vetter and Van Acker, 2005; Ritschkoff et al., 2003; Sèbe and Brook, 2001). Although some 
positive results, also conflicting data are reported about the effect of water repellents, e.g. differential leaching of arsenic, chromium and copper (Cui and Walcheski, 2000; Lebow et al., 2004).

Focus in this study was on three different biocides used in wood preservative formulations. The carbamate 3-iodo-2propynylbutylcarbamate (IPBC) was proved to be effective in protecting wood against blue stain, moulds and degrading fungi. Drawbacks are its known toxicity towards fish and daphnids (Cook et al., 2002). Testing quaternary ammonium compounds showed their effectiveness as wood protecting agents, but they may leach out and pose a threat to both mammals and humans (Donath et al., 2006b). The triazole fungistatic compound propiconazole prevents or blocks fungal growth by binding to the enzyme sterol $14 \alpha$-demethylase, thereby preventing synthesis of ergosterol, an essential part of fungal cell walls (Zarn et al., 2003). It has a good penetration and distribution in wood and a good toxicological profile and is being used to protect crops and wood (Kurti et al., 2005; Valcke, 1989).

The purpose of this research was to find out whether organosilicon compounds are able to lower biocide leaching without compromising their efficacy in protecting wood from degradation. If they do so, it is assumed that the leachates contain less biocide compared to wood treated with solely biocides and have therefore a lower impact on the environment. It is clear that both efficacy and ecotoxicology are important in this evaluation. That is why the method described by De Vetter et al. (2008) was used for this investigation.

\section{MATERIALS AND METHODS}

\subsection{Materials}

Scots pine sapwood specimens were impregnated with silicon containing organic compounds. A first product group consisted of water-based silicones. In this group a $60 \mathrm{Wt} \%$ active ingredient (Wt\% ai) macroemulsion of polydimethylsiloxane (PDMS), a $50 \mathrm{Wt} \%$ active emulsion of methoxy-terminated dimethylphenylsiloxane (DMS) and N-octyltriethoxysilane (n-OTES), a $100 \mathrm{Wt} \%$ active micro-emulsion of polydimethylsiloxane (PDMS) and triethoxysilane (TES) and a $40 \mathrm{Wt} \%$ active mixture of dimethylmethylhydrogen siloxane (DMS) and N-octyltriethoxysilane (nOTES) were tested. The second product group was composed of the solvent-based N-octyltriethoxysilane (n-OTES) (100 Wt\% ai) and a mixture of the alkoxysilanes methyltrimethoxysilane (MTM) and N-octyltriethoxysilane (n-OTES) $(100 \mathrm{Wt} \%$ ai). Except for the $100 \%$ active micro-emulsion of PDMS/TES which was purchased at Wacker-Chemie $\mathrm{GmbH}$ (Germany), all organosilicons were supplied by Dow Corning Corporation (Belgium).

The three selected biocides were 3-iodo-2-propynylbutylcarbamate (IPBC, Troy Chemical Company, The Netherlands), the SiQuaternary ammonium compound 3-(trimethoxysilyl)propyldimethyloctadecyl ammonium chloride (Si-Quat, Aegis Environments Inc, USA) and a 1:2 combination of IPBC and ( \pm -)-(cis+trans)-1-(2(2,4-dichlorophenyl)-4-propyl-1,3-dioxolan-2-yl)-methyl)-1H-1,2,4triazole (propiconazole, propi, Janssen Pharmaceutica, Belgium). These biocides were both soluble in water as well as in the organic solvent isopropylalcohol (IPA).

\subsection{Wood treatment}

Scots pine sapwood was cut into $50 \times 25 \times 15 \mathrm{~mm}^{3}$ (longitudinal $\times$ radial $\times$ tangential) specimens and these were conditioned at $20{ }^{\circ} \mathrm{C}$ and $65 \%$ relative humidity (RH) for several weeks. All organosilicons were applied in a $5 \mathrm{Wt} \%$ ai concentration, with or without biocides. The only exception was the combination of $10 \mathrm{Wt} \%$ ai MTM/n-OTES with $1 \mathrm{Wt} \%$ ai Si-Quat. The biocide IPBC was used at $0.3 \mathrm{Wt} \%$ ai concentration, also when combined with $0.6 \mathrm{Wt} \%$ ai of propiconazole. The Si-Quat was used at $2 \mathrm{Wt} \%$ ai concentration in water and at $1 \mathrm{Wt} \%$ ai concentration in IPA.

The specimens, twelve replicates per treatment, were put in a vessel and treated by impregnation under vacuum as recommended in EN 113 (1996), allowing the treating solution to flow into the vessel after $20 \mathrm{~min}$ vacuum. After re-installing the vacuum for $5 \mathrm{~min}$, the specimens were kept in the solution for another $2 \mathrm{~h}$ at atmospheric pressure. Afterwards the blocks were conditioned under ambient conditions for $48 \mathrm{~h}$ and then cured at $60{ }^{\circ} \mathrm{C}$ until they reached constant mass. The specimens were weighed prior ( $\left.m_{\text {untreated }}\right)$ and after $\left(m_{\text {treated }}\right)$ impregnation, allowing calculation of the weight percent gain (WPG) of the silicones and the biocide retentions according to equations (1) and (2).

$$
\begin{gathered}
\mathrm{WPG}_{\text {silicone }}(\%)=\frac{m_{\text {treated }}(\mathrm{g})-m_{\text {untreated }}(\mathrm{g})}{m_{\text {untreated }}(\mathrm{g})} \times \operatorname{conc}_{a i}(\%) \\
\text { retention }_{\text {biocide }}\left(\mathrm{kg} / \mathrm{m}^{3}\right)=\frac{m_{\text {treated }}(\mathrm{g})-m_{\text {untreated }}(\mathrm{g})}{\text { volume }\left(\mathrm{cm}^{3}\right)} \times \operatorname{conc}_{a i}(\%) \times 1000 .
\end{gathered}
$$

\subsection{Efficacy and ecotoxicology of silicone-treated wood}

The efficacy and ecotoxicology of silicone-treated wood was evaluated according to the methodology described by De Vetter et al. (2008). These results were then used as a basis to determine the biocides-fixation capacity of organosilicons. Scots pine sapwood specimens were, once treated, subjected to leaching and afterwards exposed to fungal decay. This methodology comprises a tiered approach of the ecotoxicology of the leachates towards the crustacean Daphnia magna. The leaching procedure according to the European Standard EN 84 (1996) was used as a worst case scenario. The method according to the OECD part 1-leaching (CEN/TR 15119, 2005) was included as a milder, more realistic procedure. The first procedure comprises an impregnation of the wood specimens, followed by refreshments of the leaching water, whereas the second procedure simulates rain events by immersions in water. For both procedures the leachates at $24 \mathrm{~h}$ and at 14 days were retained for further investigations.

The freshwater crustacean Daphnia magna was used to evaluate the ecotoxicity of the obtained leachates. The Daphtoxkit procedure (Daphtoxkit $\mathrm{F}^{\mathrm{TM}}$ magna, 2001) is based on the OECD guideline 202 (1984). Neonates were exposed to a 1:2 dilution series of the pooled leachates and incubated in the dark at $20^{\circ} \mathrm{C}$. The inhibition of mobility of the daphnids was determined after $48 \mathrm{~h}$ exposure and the Trimmed Spearman-Karber method (Hamilton et al., 1977; United States Environmental Protection Agency, 2006) was used to calculate the toxicity data being $50 \%$ effect endpoint values $\left(E C_{50} \mathrm{~s}\right)$ in $\%$ of dilution. These $E C_{50}$ values were subsequently transformed into toxic 


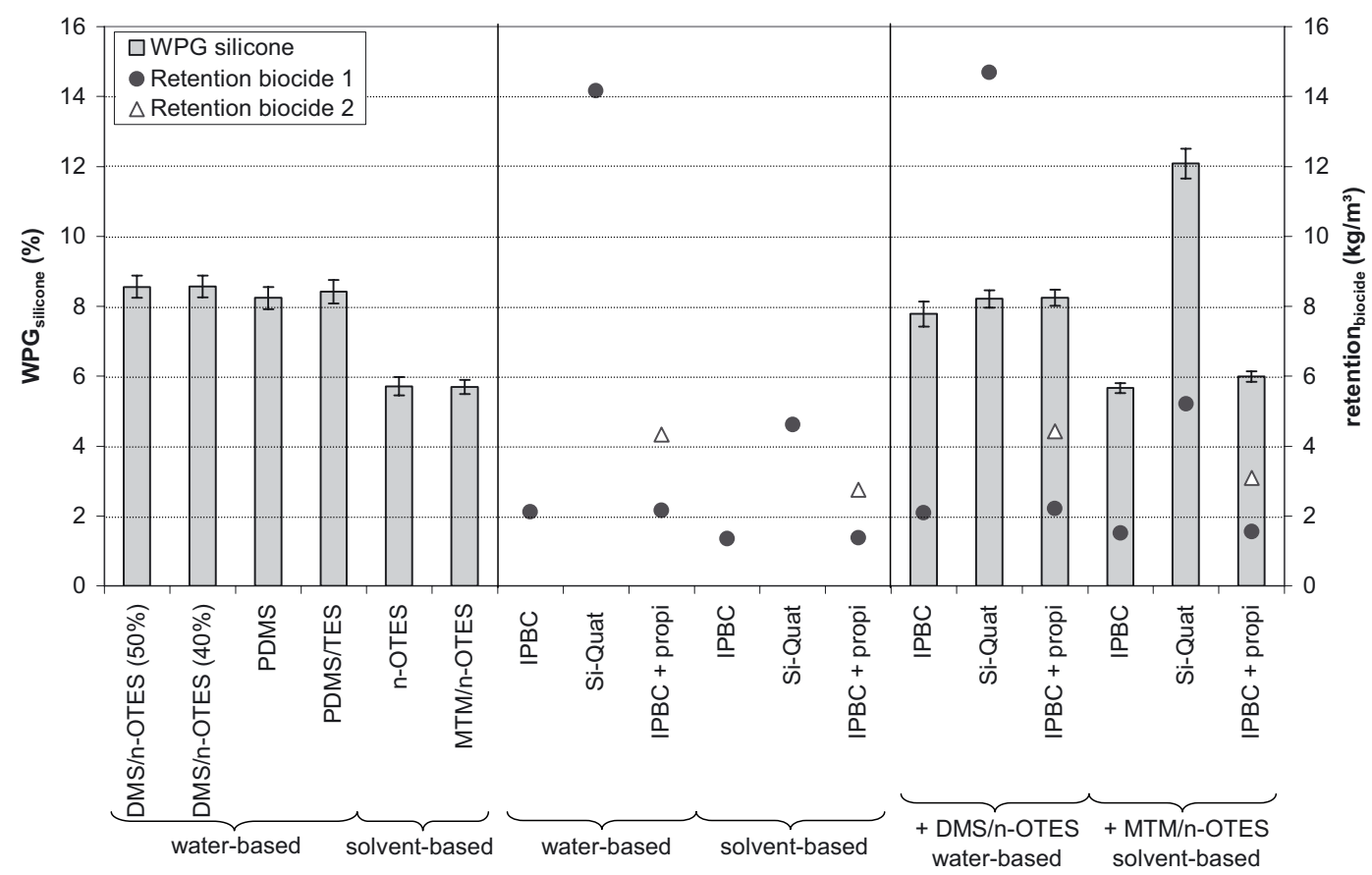

Figure 1. Weight percent gains (WPG) of organosilicons and retention values of biocides when vacuum impregnated into Scots pine sapwood EN 113-blocks. The average WPGs and their standard deviations are presented.

units (TUs) with the formula of Sprague and Ramsay (1965) as cited in Manusadžianas et al. (2003) (Eq. (3)).

$$
\mathrm{TU}=\frac{1}{E C_{50}(\%)} \times 100
$$

First all 24 h EN 84-leachates were evaluated. For those treatments showing significant toxicity the 14 day EN 84-leachate and the $24 \mathrm{~h}$ OECD part 1-leachates were assessed. When still significant ecotoxicity was observed the 14 day OECD part 1-leachate could also be evaluated. The limit for non-toxicity of 2 TUs as defined by De Vetter et al. (2008a) was taken as the threshold value for significant toxicity.

The efficacy against wood rot of the leached Scots pine sapwood specimens was tested by exposure to the brown rot fungus $C$. puteana using a malt-agar block method for 16 weeks (EN 113, 1996). After exposure the specimens (six replicates) were removed from the Kolleflasks, adhering mycelium was taken away and the blocks were dried at $103{ }^{\circ} \mathrm{C}$ and weighed $\left(m_{d r y}\right)$ to determine the percentage mass loss $(M L)$ of the wood substance, taking into account a correction value $C$ linked to non fungal mass loss (Eq. (4)).

$$
M L(\%)=\left[\frac{m_{\text {untreated }}-m_{\text {dry }}}{m_{\text {untreated }}} \times 100\right]-C .
$$

\section{RESULTS}

\subsection{Efficacy and ecotoxicology of silicone treated wood}

First of all the efficacy and ecotoxicology of organosilicon treated wood was determined. Figure 1 gives the WPGs of the silicones of the treated wood. Figure 2 illustrates that when the mass losses due to fungal attack are evaluated according to the
European Standard EN 599 (1996), no single treatment can protect Scots pine sapwood effectively against attack by the brown rotter $C$. puteana since all mass losses are higher than the critical value of $3 \%$. However, when the mass losses are used to determine the durability class according to CEN/TS 15083-1 (2006) the results can be interpreted differently. Figure 2 shows that the solvent-based MTM/n-OTES and the $40 \mathrm{Wt} \%$ water-based DMS/n-OTES improve the durability of Scots pine sapwood from class 5 to class 4 . The water-based $100 \mathrm{Wt} \%$ PDMS/TES applied at 5\% ai concentration can improve the decay resistance of Scots pine against $C$. puteana with even two durability classes. These results indicate that both water- and solvent-based organosilicons applied at low concentrations are able to induce an improvement in durability of Scots pine up to durability class 3 . However they do not reach full protection like wood preservatives (De Vetter et al., 2008).

The ecotoxicity values of the EN 84-leachates after 1 day are very low and all below 2 TUs (Fig. 3). Since these leachates are obtained with the harshest method it can be concluded that organosilicon treated wood will most probably not pose any threat to the environment when used outdoors under out of ground contact conditions (EN 335-1, 2006). The assessment of the ecotoxicity against D. magna of the other, milder leachates was therefore not carried out.

\subsection{Efficacy and ecotoxicology of biocide treated wood}

The biocide retentions of the different impregnations are presented in Figure 1. Figure 2 shows that all mass losses 




Figure 2. Mass losses of EN 84-aged Scots pine sapwood EN 113-specimens treated with organosilicons, biocides or both after 16 weeks exposure to C. puteana. The averages and their standard deviations are presented. The dashed line represents the critical value of $3 \%$ mass loss for full preservative effectiveness (EN 599, 1996).

of Scots pine sapwood treated with biocides and exposed to C. puteana are below the critical value of 3\%, indicating they fulfil the requirements of an effective wood preservative treatment (EN 599, 1996).

The toxic units of the leachates differ from each other (Fig. 3). Wood treated with IPBC yields 1 day EN 84leachates having extremely high TUs, respectively 84 and 74 TUs when applied in a water-based or solvent-based solution. These leachates with extremely high TUs are followed by the leachates of wood treated with a combination of IPBC and propiconazole, yielding approximately 30 TUs. The least toxic leachates are those originating from wood treated with either 1 or $2 \%$ ai Si-Quat. The lowest (solvent-based) concentration gives rise to 6 TUs, whereas the highest (water-based) concentration results in 11 TUs. The difference in toxicity of the leachates by a factor $2(11 / 6$ TUs) is corresponding to the proportion of the concentrations in Si-Quat (2/1\% ai) between the water-based and solvent-based solutions. The observed leaching of the Si-Quat therefore appears to be concentration dependent. Since these 1 day EN 84-leachates are resulting in TU values higher than the limit value of 2, the EN 84-leachates after 14 days and the OECD part 1-leachates after 1 day were also examined. Except for the water-based treatments containing IPBC or IPBC plus propiconazole having 6 and 5 TUs respecitvely, the TUs of these leachates are below the 2 TUs limit.

These values show that part of the biocides leach out during EN 84-leaching and harm the D. magna. The remaining biocides in the wood blocks are still able to protect the wood effectively against attack by $C$. puteana.

\subsection{Combining silicones and biocides in wood protection}

Figure 1 shows that the WPGs of the silicones and the biocide retentions reach the same levels when applied in combination or on their own. Since the solvent-based MTM/n-OTES is applied at $10 \%$ ai concentration in combination with $1 \mathrm{Wt} \%$ Si-Quat it is logic that the obtained WPG is approximately double as high then when applied at $5 \mathrm{Wt} \%$ ai concentration like in all other applications.

The addition of an organosilicon to a biocide containing solution does not have a significant impact on the efficacy in protecting Scots pine sapwood against attack by $C$. puteana (Fig. 2). Again all mass losses are well below the critical mass loss limit of $3 \%$ and the wood is consequently very durable.

Also the ecotoxicology of the resulting leachates does not differ that much from those of solely biocide-treated Scots pine (Fig. 3). Indeed, taking the $95 \%$ confidence intervals into account, the same corresponding toxicity is observed for the leachates of Scots pine treated with solely biocides and those treated with a combination of a biocide and an organosilicon. The only exceptions are the 1 day EN 84-leachates of Scots pine sapwood impregnated with water-based IPBC and propiconazole or impregnated with solvent-based IPBC. The first biocide mixture generates higher toxicity and the second biocide lower toxicity when applied in combination with an organosilicon. Once more the ratio of applied concentration Si-Quat $(2 / 1 \%$ ai) to the wood blocks is roughly equal to the ratio of TUs of the wood leachates (11.4/6.4 TUs). Due to the high toxicities also the 14 days EN 84-leachates and the 1 day OECD part 1-leachates were examined. Although the 


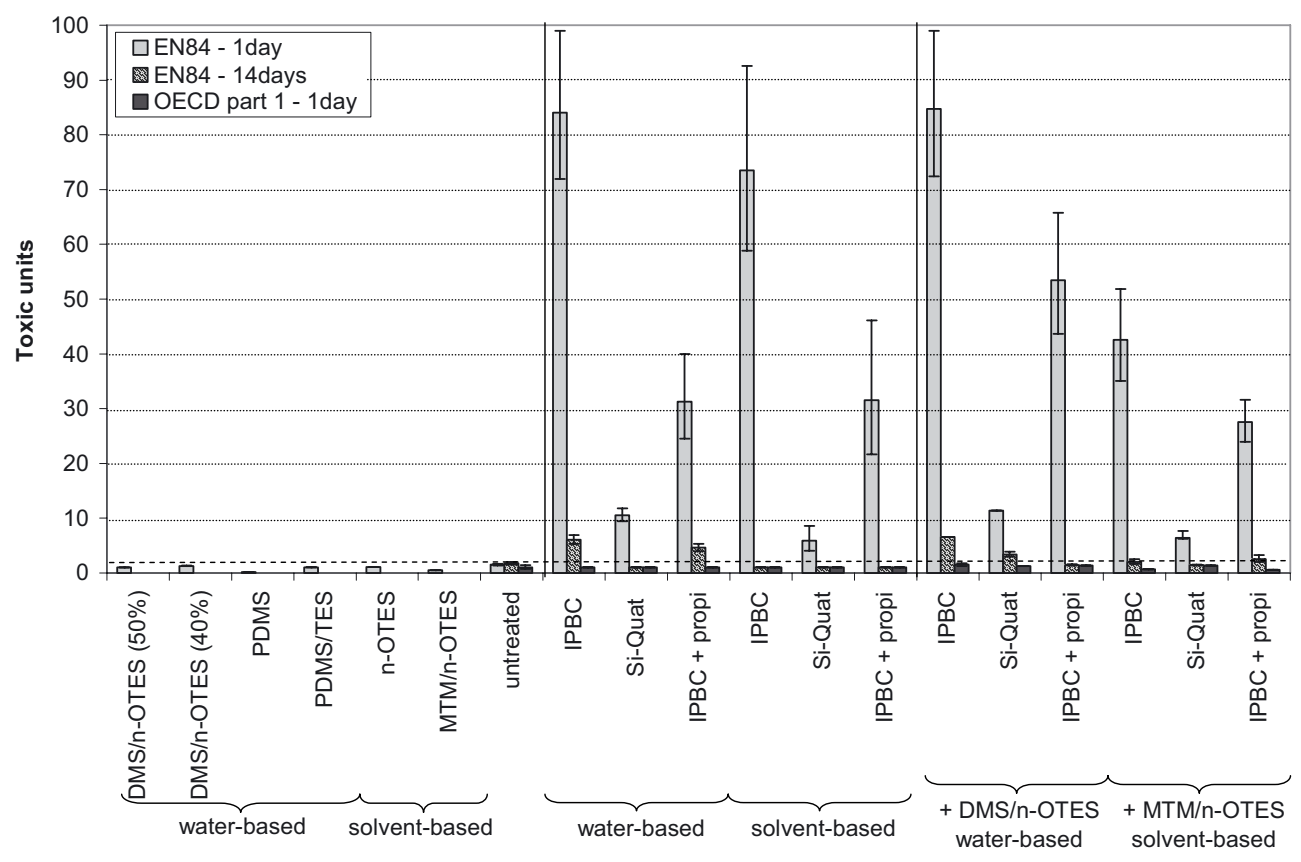

Figure 3. Toxic units of different leachates of Scots pine sapwood impregnated with organosilicons, biocides or both. The bars represent the $95 \%$ confidence intervals of the toxic units. The dashed line is situated at 2 toxic units.

EN 84-leachate after 14 days of $50 \mathrm{Wt} \%$ DMS/n-OTES plus IPBC treated wood is still slightly toxic (6.6 TUs), all other leachates have toxicities approximating or lower than 2 TUs. This means that it can be assumed none of the combinations would induce significant toxicity in real life leaching. Therefore it was not considered valuable to evaluate 14 days OECD part 1-leachates.

Considering both the toxicities of leachates from wood treated with solely biocides or in combinations with organosilicons, Figure 3 shows that the toxicities decrease over time. More precisely the toxicity to D. magna after 14 days EN 84-leaching is 3 to 37 times smaller than after 1 day, resulting in $<2$ to 6.6 TUs after 14 days leaching. Furthermore the toxicity of the OECD part 1-leachates was even lower $(<$ 2 TUs). The EN 84-leachates indicate that the solvent-based treatments are less toxic to Daphnia magna than their corresponding water-based combinations, regardless the time of harvesting.

\section{DISCUSSION}

Different investigations were undertaken to evaluate the effectiveness of organosilicons in protecting wood from fungal decay. For most treatments no full protection could be guaranteed to the wood when the organosilicons were applied at low concentrations (De Vetter et al., 2009; De Vetter and Van Acker, 2005; Goethals and Stevens, 1994; Hill et al., 2004). Nevertheless some significant protective effectiveness is observed. None of the organosilicons applied at $5 \mathrm{Wt} \%$ ai is able to protect the wood up to decay rates below $3 \%$ mass loss. However some treatments can enhance the durability with 1 or 2 classes, making the treated wood suitable for applications under use class 3 conditions. Furthermore the ecotoxicity results are very promising since the values are comparable to the value of untreated Scots pine sapwood leachate, which is considered not to be toxic (De Vetter et al., 2008).

Although the common use of IPBC limited literature data are available on the required effective concentrations against wood destroying basidiomycetes. Hansen (1984) reported toxic values of IPBC treated Scots pine against $C$. puteana of $0.2-0.4 \mathrm{~kg} / \mathrm{m}^{3}$ for unleached and $0.3-0.5 \mathrm{~kg} / \mathrm{m}^{3}$ for EN 84-leached EN 113-specimens. Cserjesi et al. (1984) showed that IPBC was ineffective in controlling fungal growth (mould, stain fungi but especially degrading fungi) on spruce-pine-fir lumber dipped in a solution at a concentration as high as $0.8 \%$ active ingredient IPBC. However, in this study quite high concentrations of IPBC were tested. A preservative concentration of approximately $0.3 \mathrm{Wt} \%$ ai induced a retention of about $1.3-$ $2.0 \mathrm{~kg} \mathrm{IPBC} / \mathrm{m}^{3}$. Therefore it is not surprising that the Scots pine is protected effectively against brown rot decay, irrespective the addition of an organosilicon to the treating solution.

Published information on the toxicity of IPBC towards D. magna is very scant. While Farrell et al. (1998) found that D. magna was the most sensitive species among both invertebrates as well as fishes with an $\mathrm{LC}_{50}$ of $40 \mu \mathrm{g}$ IPBC/L, Henderson (1992) reported a $48 \mathrm{~h} \mathrm{LC}_{50}$ as high as $645 \mu \mathrm{g}$ IPBC/L. This study reports the ecotoxicities of leachates of IPBC treated wood using high preservative concentrations. It is not surprising that the leachates are toxic and it is clear that lower concentrations of IPBC would still be effective against decay and yield lower toxicity towards $D$. magna.

Donath et al. (2006b) have treated Scots pine and beech mini-blocks with a multifunctional silane alone or in 
combination with 3-(trimethoxysilyl)propyldimethyloctadecyl ammonium chloride (Si-Quat). After EN 84 leaching the recorded mass losses were about the same irrespective the addition of the Si-Quat to the treating solutions. They assume that the $\mathrm{Si}$-Quat is either incorporated into the siloxane matrix of the silane or that it is fixed to the wood cell wall. Incorporation of the Si-Quat would prevent mould fungi of being able to degrade quats, a functionality reported by Dubois and Ruddick (1998). Since in this study the same toxicity (and corresponding concentration of Si-Quat) is found for the leachates irrespective the addition of an organosilicon, fixation to the wood cell wall seems the most plausible.

Isquith et al. (1972) demonstrated that the Si-Quat had antimicrobial activity in a serial tube dilution method without entering the cell and attributed this activity to membrane phenomena. Donath et al. (2006b) proved the Si-Quat to be also effective in protecting Scots pine sapwood against fungal decay by $C$. puteana when incorporated in a siloxane matrix. The Si-Quat was applied at a concentration of at least $0.5 \%$ ai in combination with 5\% ai multifunctional silane. In this study such a low concentration was not tested but the full protection reached at $1 \mathrm{Wt} \%$ ai Si-Quat suggests that even lower concentrations could suffice to protect Scots pine sapwood effectively against attack by $C$. puteana. Nevertheless, as Briscoe et al. (1990) pointed out for several wood preservatives the evaluation of a new wood preservative should always include a test using natural mixed microbial populations to see its effectiveness in real exposure conditions.

Toxic values of solvent-based propiconazole for Scots pine EN 113 impregnated specimens against $C$. puteana are determined to be between $0.27-0.39 \mathrm{~kg}$ ai $/ \mathrm{m}^{3}$ for unaged specimens and between $0.20-0.31 \mathrm{~kg}$ ai $/ \mathrm{m}^{3}$ for EN 84-leached specimens (Valcke, 1989; Valcke and Stevens, 1991). For Scots pine sapwood EN 113-specimens treated with water-based propiconazole and exposed under the same circumstances, toxic values lower than $0.370 \mathrm{~kg} \mathrm{ai} / \mathrm{m}^{3}$ for unaged specimens and between $0.42-0.60 \mathrm{~kg} \mathrm{ai} / \mathrm{m}^{3}$ for EN 84-leached specimens are found (Buschhaus and Valcke, 1995). However, Valcke and Stevens (1991) pointed out that an equal or preferentially a higher loading at the outermost shell of EN 113-specimens is necessary to protect the wood effectively against fungal attack, and this especially when the wood is treated superficially. In this research a combination of $0.6 \mathrm{Wt} \%$ ai propiconazole and $0.3 \mathrm{Wt} \%$ ai IPBC protects the wood sufficiently, irrespective the solvent used (water or IPA) or the addition of a $5 \mathrm{Wt} \%$ ai organosilicon. It was shown before that leaching and evaporative ageing did not have a negative impact on the protective effectiveness of propiconazole (Valcke, 1989; Valcke and Stevens, 1991).

Propiconazole is one of the best characterized chemicals interfering with the embryonic development of D. magna, although up to now only acute toxicities of the chemical itself are reported (Soetaert et al., 2006; Wegen, 1991). Since in the present research propiconazole was combined with IPBC and no chemical analyses on the leachates were performed no exact toxicity values can be calculated for propiconazole. However, it was observed that Scots pine treated with a combination of IPBC and propiconazole yields lower leachate toxicities than when Scots pine is treated with the same concen- tration of solely IPBC. Although it has been reported before that the formulation type has a major impact on the final result (Valcke, 1989), in this research only minor effect of the solvent was noticed. At the concentrations mentioned before, wood is protected effectively against fungal decay, but high leachatetoxicities are recorded. It is therefore suggested to lower the amount of product applied which might also lead to some significant impact on leached fungicides when organosilicons are added.

\section{CONCLUSION}

As a final conclusion it can be postulated that organosilicons applied at low concentrations are not able to protect Scots pine sapwood specimens fully from fungal decay and that their leachates are not harmful to the crustacean D. magna. Biocidetreated Scots pine specimens are protected effectively against fungal attack, but their leachates yield a high toxicity towards D. magna. This ecotoxicity level depends both on the preservative and concentration applied. Combining the organosilicons and biocides in the treating solution does not change the protective effectiveness of the treated wood, but does not reduce the toxicity of their leachates either. These observations are valid both for water-based and solvent-based impregnating solutions. The authors would like to stress that this conclusion is valid for the test setup as described in this research: using a high amount of biocide and only a small amount of organosilicon. To lower the toxicity towards D. magna a lower amount of biocide is desirable. Since the mass loss results for fungal testing are well below 3\% this might still be effective against fungal attack. Whether under these circumstances a higher amount of silicones would be effective in preventing leaching should be further investigated. Nevertheless also economic constraints related to the addition of the organosilicons should be considered.

However, this does not mean that adding an organosilicon to a biocide containing treating solution could not have an added value. The organosilicons may have a positive effect on the wood-moisture relationship reducing moisture related damage like surface erosion, defibrillation, crack formation etc. of the wood and thereby contributing to a longer service life of the treated wood.

Acknowledgements: We would like to express our gratitude to Dow Corning Corporation for supplying the organosilicons and to Troy Corporation, AEGIS Environments Inc. and Janssen Pharmaceutica $\mathrm{nv}$ for providing the biocides. The authors are gratefull to the European Commision for funding the Research Project 'Improvement of Wood Product Properties by Increased Hydrophobicity Obtained by the Use of Silicon Compounds' - HYDROPHOB (QLK5-CT-200201439), which was the framework for this study.

\section{REFERENCES}

Briscoe P.A., Williams G.R., Anderson D.G., and Gadd G.M., 1990. Microbial tolerance and biodetoxification of organic and organometallic biocides. The International Research Group on Wood Preservation, Document No. IRG/WP 1464, 12 p. 
Buschhaus H.U. and Valcke A., 1995. Triazoles: Synergism between propiconazole and tebuconazole. The International Research Group on Wood Preservation, Document No IRG/WP 95-30092, 2 p.

CEN/TR 15119, 2005. Durability of wood and wood-based products. Estimation of emissions from preservative treated wood to the environment. Laboratory method, Brussels: European Committee for Standardization.

CEN/TS 15083-1, 2006. Durability of wood and wood-based products. Determination of the natural durability of solid wood against wooddestroying fungi, test methods. Part 1: Basidiomycetes, Brussels: European Committee for Standardization.

Cook S.R., Sullivan J., and Dickinson D.J., 2002. The bacterial biotransformation of IPBC. The International Research Group on Wood Preservation Document No IRG/WP 02-10437, 9 p.

Cserjesi A.J., Byrne A., and Johnson E.L., 1984. Long-term protection of stored lumber against mould, stain, and specifically decay: a comparative field test of fungicidal formulations. The International Research Group on Wood Preservation, Document No IRG/WP 3281, 7 p.

Cui F. and Walcheski P., 2000. The effect of water-repellent additives on the leaching of CCA from simulated southern yellow pine decks. The International Research Group on Wood Preservation, Document No IRG/WP 00-50158, 8 p.

Daphtoxkit $\mathrm{F}^{\mathrm{TM}}$ magna, 2001. Crustacean toxicity screening test for freshwater. Standard operational procedure: MicroBioTests Inc., Mariakerke, Belgium.

De Vetter L., Cnudde V., Masschaele B., Jacobs P.J.S., and Van Acker J., 2006. Detection and distribution analysis of organosilicon compounds in wood by means of SEM-EDX and Micro-Ct. Mater. Charact. 56: 39-48.

De Vetter L., Depraetere G., Janssen C., Stevens M., and Van Acker J., 2008. Methodology to assess both the efficacy and ecotoxicology of preservative treated and modified wood. Ann. For. Sci. 65: 504.

De Vetter L., Stevens M., and Van Acker J., 2009. Fungal decay resistance and durability of organosilicon-treated wood. Int. Biodeterior. Biodegrad. 63: 130-134.

De Vetter L. and Van Acker J., 2005. Standard testing of organosilicon compounds as wood modification agents. In: Militz H. and Hill C. (Eds.), Second European Conference on Wood Modification, Göttingen, pp. 232-241.

Donath S., Militz H., and Mai C., 2006a. Creating water-repellent effects on wood by treatment with silanes. Holzforschung 60: 40-46.

Donath S., Militz H., and Mai C., 2006b. Treatment of wood with aminofunctional silanes for protection against wood destroying fungi. Holzforschung 60: 210-216.

Dubois J.W. and Ruddick J.N.R., 1998. The fungal degradation of quaternary ammonium compounds in wood. The International Research Group on Wood Preservation, Document No IRG/WP 98-10263, $10 \mathrm{p}$.

EN 84, 1996. Wood preservatives. Accelerated ageing of treated wood prior to biological testing. Leaching procedure, Brussels: European Committee for Standardization.

EN 113, 1996. Wood preservatives. Test method for determining the protective effectiveness against wood destroying basidiomycetes. Determination of the toxic values, Brussels: European Committee for Standardization.

EN 335-1, 2006. Durability of wood and derived materials. Definition of use classes. Part 1: General, Brussels: European Committee for Standardization.

EN 599, 1996. Durability of wood and wood-based products. Performance of preventive wood preservatives as determined by biological tests. Part 1: Specification according to hazard class, Brussels: European Committee for Standardization.

Farrell A.P., Stockner E., and Kennedy C.J., 1998. A study of the lethal and sublethal toxicity of Polyphase P-100, an antisapstain fungicide containing 3-iodo-2-propynyl butyl carbamate (IPBC), on fish and aquatic invertebrates. Arch. Environ. Contam. Toxicol. 35: 472-478.
Goethals P. and Stevens M., 1994. Dimensional stability and decay resistance of wood upon modification with some new type chemical reactants. The International Research Group on Wood Preservation, Document No. IRG/WP 94-40028, 14 p.

Hamilton M.A., Russo R.C., and Thurston R.V., 1977. Trimmed Spearman-Karber method for estimating median lethal concentrations in toxicity bioassays. Environ. Sci. Technol. 11: 714-718.

Hansen J., 1984. IPBC - A new fungicide for wood protection. The International Research Group on Wood Preservation, Document No. IRG/WP 3295, 7 p.

Henderson N.D., 1992. A review of the environmental impact and toxic effects of IPBC, US: Environmental Protection Division.

Hill C.A.S., Farahani M.R.M., and Hale M.D.C., 2004. The use of organo alkoxysilane coupling agents for wood preservation. Holzforschung 58: 316-325.

Isquith A.J., Abbott E.A., and Walters P.A., 1972. Surface-bonded antimicrobial activity of an organosilicon quaternary ammonium chloride. Appl. Microbiol. 24: 859-863.

Kurti E., Heyd D.V., and Wylie R.S., 2005. Raman microscopy for the quantification of propiconazole in white spruce. Wood Sci. Technol. 39: 618-629.

Lebow S., Foster D., and Lebow P., 2004. Rate of CCA Leaching From Commercially Treated Decking. For. Prod. J. 54: 81-88.

Mai C. and Militz H., 2004. Modification of wood with silicon compounds. Treatment systems based on organic silicon compounds a review. Wood Sci. Technol. 37: 453-461.

Manusadžianas L., Balkelytë L., Sadauskas K., Blinova I., Põllumaa L., and Kahru A., 2003. Ecotoxicological study of lithuanian and estonian wastewaters: selection of the biotests, and correspondence between toxicity and chemical-based indices. Aquat. Toxicol. 63: $27-41$.

OECD, 1984. Guideline for testing of chemicals. Daphnia sp., acute immobilisation and reproduction test: Organisation for Economic Cooperation and Development.

Ritschkoff A.C., Mahlberg R., Suomi-Lindberg L., Viikari L., and Nurmi A., 2003. Properties of wood treated with hydrophobisation agents. In: Van Acker J. and Hill C. (Eds.), First European Conference on Wood Modification, Ghent, pp. 267-271.

Sèbe G. and Brook M.A., 2001. Hydrophobization of wood surfaces: covalent grafting of silicone polymers. Wood Sci. Technol. 35: 269282.

Soetaert A., Moens L.N., Van der Ven K., Van Leemput K., Naudts B., Blust R., and De Coen W.M., 2006. Molecular impact of propiconazole on Daphnia magna using a reproduction-related cDNA array. Comp. Biochem. Physiol. 142: 66-76.

Taylor J.L. and Cooper P.A., 2003. Leaching of CCA from lumber exposed to natural rain aboveground. For. Prod. J. 53: 81-86.

United States Environmental Protection Agency, 2006. Trimmed Spearman-Karber programme.

Valcke A., 1989. Suitability of propiconazole (R 49362) as a newgeneration wood-preserving fungicide. The International Research Group on Wood Preservation, Document No IRG/WP 3529, 17 p.

Valcke A.R. and Stevens M., 1991. Stability, performance and distribution of propiconazole ( $\mathrm{R}$ 49362) in acceleratedly aged wood. The International Research Group on Wood Preservation, Document No IRG/WP 3647, $18 \mathrm{p}$.

Wegen H.W., 1991. Organic solvent preservatives essays on the ecotoxicology of new formulations. The International Research Group on Wood Preservation, Document No IRG/WP 3642, 22 p.

Zahora A., 2000. Long-term performance of a "wax" type additive for use with water-borne pressure preservative treatments. The International Research Group on Wood Preservation, Document No IRG/WP 0040159, $13 \mathrm{p}$.

Zarn J.A., Brüschweiler B.J., and Schlatter J.R., 2003. Azole fungicides affect mammalian steroidogenesis by inhibiting sterol $14 \alpha-$ demethylase and aromatase. Environ. Health Perspect. 111: 255-261. 